\title{
Variation in the distribution of Antarctic krill Euphausia superba around South Georgia
}

\author{
J. L. Watkins*, A. W. A. Murray, H. I. Daly \\ British Antarctic Survey, Natural Environment Research Council, High Cross, Madingley Road, Cambridge CB3 OET, \\ United Kingdom
}

\begin{abstract}
There is considerable spatial structure within the South Georgia krill-based ecosystem in terms of predator demand, commercial fishery pressure and krill abundance. Here we investigate the hypothesis that there is also spatial structure in the krill population composition, finding differences in length-frequency histograms between the eastern and western ends of the island. Between 1981 and 1997 the British Antarctic Survey carried out 6 major cruises where krill were taken from both ends of South Georgia. Cluster analysis revealed that the length-frequency histograms could be grouped into 4 main types with relatively simple biological characteristics: Cluster 1 contained small krill (mean size $23.9 \mathrm{~mm}$ ) up to 2 yr old ( $1+$ yr class); Cluster 2 (mean size $31.1 \mathrm{~mm}$ ) contained a mixture of $1+$ with some $2+$ and $3+$ yr classes; Cluster 3 contained medium-sized krill (mean size $41.4 \mathrm{~mm}$ ) probably $2+$ and $3+$ yr classes; Cluster 4 contained large $\mathrm{krill}$ (mean size $50.3 \mathrm{~mm}$ ) likely to be $3+$ or older. Principal components analysis (PCA) provided good separation of these clusters using the first 2 axes ( $80 \%$ of the total variance). There were no obvious differences in the length composition of krill sampled from different water depths, although there were some indications that differences did occur between different water masses. Detailed inspection of the individual cruises revealed that the length-frequency histograms at the western end of the island contained more large krill than those from the eastern end of the island and also that when Weddell Sea water was found within a cruise then this contained the smallest krill. We consider that such differences may arise not only because krill may experience different conditions at each end of the island but also may originate from 2 separate sources which may have different population structures.
\end{abstract}

KEY WORDS: Antarctic krill · Euphausia superba $\cdot$ South Georgia $\cdot$ Population structure

\section{INTRODUCTION}

The distribution of Antarctic krill Euphausia superba has been the focus of extensive research for many years (see for instance Marr 1962, Voronina 1974 , Everson 1976, Amos 1984, Priddle et al. 1988, Trathan et al. 1993) and these studies have illustrated the complicated and sometimes unpredictable nature of krill populations. The waters around South Georgia are known to support high concentrations of krill (Marr 1962, Jazdzewski et al. 1978, Brierley et al. 1997). Given the lack of early larval stages detected in the area (Marr 1962, Ward et al. 1990) and the prevailing currents (Hofmann et al. 1998), it is likely that these

\footnotetext{
·E-mail: j.watkins@bas.ac.uk
}

krill are transported into the region in Antarctic Circumpolar Current (ACC) or Weddell Sea (WS) water (Mackintosh 1973, Everson 1976). During summer the huge colonies of penguins and seals which breed on South Georgia are heavily dependent on the local krill concentrations for their breeding success (Croxall et al. 1988, Reid \& Arnould 1996). The distribution of 2 major krill predators (Macaroni penguin Eudyptes chrysolophus and Antarctic fur seal Arctocephalus gazella) indicate that the western end of South Georgia is subject to substantially greater foraging pressure than the eastern end of the island (Everson 1984, Boyd 1993, Trathan et al. 1996). In the winter there is a regular fishery (Everson \& Goss 1991) for krill, with peak catches exceeding $256000 \mathrm{t}$ in 1987 (Anon. 1993). In contrast to the distribution of predators, commercial fishing effort is frequently concentrated on banks and 

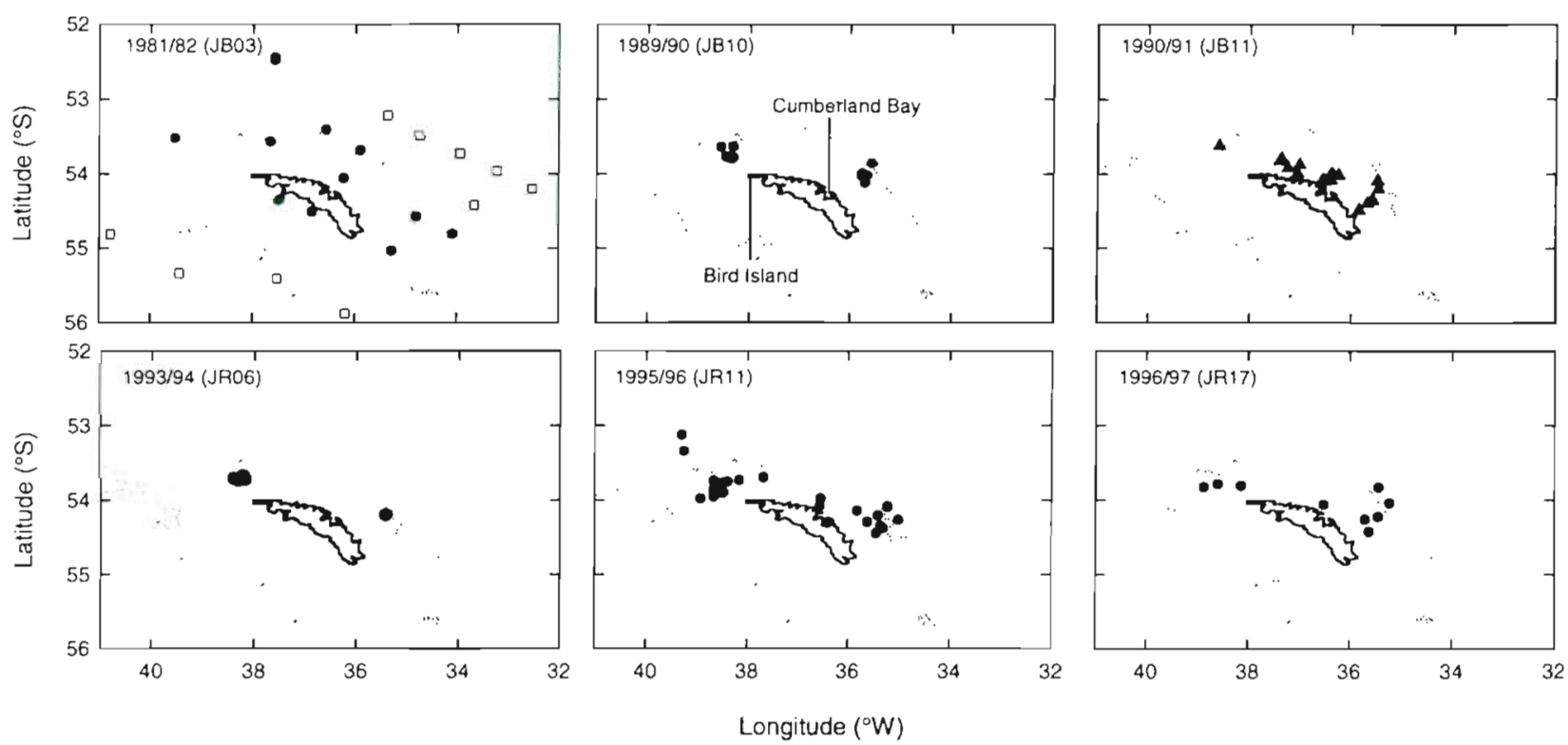

Fig. 1. Distribution of hauls used in analysis by cruise. $1000 \mathrm{~m}$ bathymetric contour is shown on each chart. (4) hauls taken in an unclassified water mass; $(\bullet)$ hauls taken in ACC water $(\square)$ hauls taken in Weddell Sea water

areas of the shelf towards the eastern end of the island (Murphy et al. 1997). There is not only considerable interannual variation in the quantity of krill found around South Georgia during the summer (Fedulov et al. 1996. Brierley et al. 1997) but also krill biomass at the eastern end of the island is often greater that at the western end (Brierley et al. 1998). There is therefore evidence of marked differences in ecosystem structure at the 2 ends of the island. A difference in population structure of krill along the north coast of South Georgia was described by Jazdzewski et al. (1978). In the light of this result and given the other changes noted above, we propose that there is a consistent difference between the krill population structure at the 2 ends of the island, with larger krill being more frequently found at the western end of the island.

In this paper we present further evidence in support of this hypothesis on the population structure of Antarctic krill around South Georgia from cruises of RRS 'John Biscoe' and RRS 'James Clark Ross' between 1981 and 1997. We first derive a simple index of krill population structure using cluster analysis, then use this index to describe spatial pattern around the island during each cruise. Finally we consider how such spatial variability may have arisen and assess the implications for predators.

\section{MATERIALS AND METHODS}

Field sampling. Data on spatial distribution and size of Euphausia superba were collected on 11 surveys carried out by the British Antarctic Survey between 1980 and 1997; of these cruises 6 have, as minimum spatial coverage, samples obtained from several distinct sites along the north side of South Georgia (Fig. 1) and will be considered in this paper. Krill were sampled using 6 different types of net (RMT8, RMT25, MNET, FNET, VKSS and LHPR; Table 1), although the majority of samples considered in this paper were taken with an RMT8 (Table 2). The surveys include hauls at pre-selected stations and hauls target-fished through acoustically-detected aggregations. Station hauls, mostly using the RMT8, were oblique hauls and, while there were slight differences in sampling strategy between cruises, were usually taken from surface

Table 1 Summary of characteristics of nets used in cruises between 1981 and 1997

\begin{tabular}{|lccc|}
\hline Net type & $\begin{array}{c}\text { Mouth } \\
\text { area } \\
\left(\mathrm{m}^{2}\right)\end{array}$ & $\begin{array}{c}\text { Towing } \\
\text { speed } \\
\left(\mathrm{m} \mathrm{s}^{-1}\right)\end{array}$ & $\begin{array}{c}\text { No. of } \\
\text { nets }\end{array}$ \\
\hline $\begin{array}{l}\text { RMT8 - Rectangular } \\
\text { midwater trawl }\end{array}$ & 8 & 1.25 & 3 \\
$\begin{array}{l}\text { RMT25 - Rectangular } \\
\text { midwater trawl }\end{array}$ & 25 & 1.25 & 2 \\
$\begin{array}{l}\text { MNET - Multi-net } \\
\text { FNET - Foredeck net } \\
\text { deployed at surface }\end{array}$ & 2 & 2.0 & 9 \\
$\begin{array}{l}\text { VKSS - Vertical krill } \\
\text { swarm sampler }\end{array}$ & 4 & 1.25 & 1 \\
$\begin{array}{l}\text { LHPR - Longhurst-hardy } \\
\text { plankton recorder }\end{array}$ & 0.11 & 20 & $>60$ \\
\hline
\end{tabular}


to $250 \mathrm{~m}$ (or to within $20 \mathrm{~m}$ of the bottom if shallower). In addition a horizontal FNET haul at the surface was usually carried out at each station. Targeted hauls, using the RMT8, MNET or VKSS, often produced large catches of krill from the targeted aggregation but provided little data on any krill outside the main aggregation; the depth ranges of these hauls were usually quite restricted.

Sample analysis. The total length (AT), from the anterior edge of the eye to the tip of the telson and rounded to the nearest mm below (Morris et al. 1988), was measured in a random subsample of 100 individuals from each net

Data analysis. An analysis of variance of length for each cruise using REML methodology in GENSTAT (Payne et al. 1993) showed that the component of variance between hauls was considerably greater than the variance component between nets within a single haul (Table 3). As a consequence, length frequencies from multiple nets within a single haul were combined without weighting for the size of catch in each net. We believe, like Mackintosh (1973), that sample sizes in small nets may vary irrespective of average local population density and thus weighted length frequencies may be quite misleading.

We used cluster analysis to derive a general classification index of krill length-frequency histogram shape. An hierarchical cluster analysis for all the net hauls in the 6 cruises was carried out using GENSTAT (Payne et al. 1993). The input to this analysis was a similarity matrix which was calculated treating the percentage frequency in each class as an euclidean coordinate from which a distance measure was calculated and standardising by a range of 100 for each class. The clustering was performed using the complete linkage (furthest neighbour) algorithm which defines the distance between 2 clusters to be the maximum distance between any 2 units in those clusters, thus tending to produce compact clusters. The analysis presented here utilized $10 \mathrm{~mm}$ length classes and produced clusters that reflected the general patterns detected by detailed visual examination of the extensive data sets; more classes gave too much noise to discern patterns and fewer did not adequately reflect the variety of shapes observed.

Principal components analysis (PCA) was also carried out using GENSTAT on the correlation matrix of the length-frequency data as used in the cluster analysis. Resuits of the PCA were plotted on biplots with each net haul classified by cruise, geographical region, bathymetry, water mass and type of krill histogram vectors showing the projections of the original data variables in $\mathrm{PC}$ space were also plotted. Histogram type was classified according to a subjective assessment of the shape of the length-frequency distribution. Six categories of size distribution were distinguished; small unimodal distributions (S) which correspond to $1+$ yr class, large unimodal distributions (L) which correspond to $2+$ yr class or older, bimodal distributions skewed towards small krill (Bs), bimodal distributions skewed towards large krill (Bl), bimodal with an even split between small and large krill (B), and even distributions with no obvious mode $(E)$. Net hauls were also categorized according to water mass origin, position around island and water depth. Water mass classifications for net hauls on cruises JB03, JB06, and JB10 were taken from data sets interpreted by Whitehouse et al. (1996). Those authors used a simple classification into ACC water or WS water on the basis of temperature profiles. In later cruises, JR11 and JR17, water

Table 3. Summary of analysis of variance of Euphausia superba length frequencies

\begin{tabular}{|c|c|c|c|c|c|c|c|c|}
\hline \multirow[t]{2}{*}{ Cruise } & \multirow{2}{*}{$\begin{array}{l}\text { No. of } \\
\text { hauls }\end{array}$} & \multirow{2}{*}{$\begin{array}{l}\text { Mean AT } \\
(\mathrm{mm})\end{array}$} & \multicolumn{3}{|c|}{ Variance components } & \multicolumn{3}{|c|}{ SE of variance components } \\
\hline & & & Hauls & Nets & Units & Hauls & Nets & Units \\
\hline $\mathrm{JB} 03$ & 22 & 30.0 & 43.16 & - & 48.68 & 13.41 & - & 0.99 \\
\hline $\mathrm{JB} 10$ & 17 & 44.7 & 19.79 & 4.21 & 29.57 & 8.88 & 1.78 & 0.83 \\
\hline JB11 & 18 & 40.1 & 1.39 & 0.06 & 15.12 & 0.56 & 0.15 & 0.48 \\
\hline JR06 & 7 & 43.4 & 31.95 & 1.07 & 29.09 & 12.00 & 0.85 & 1.20 \\
\hline JR11 & 29 & 31.2 & 26.28 & 1.67 & 28.80 & 7.52 & 0.90 & 0.69 \\
\hline JR17 & 10 & 40.2 & 35.01 & 10.81 & 33.84 & 20.52 & 5.95 & 1.20 \\
\hline
\end{tabular}




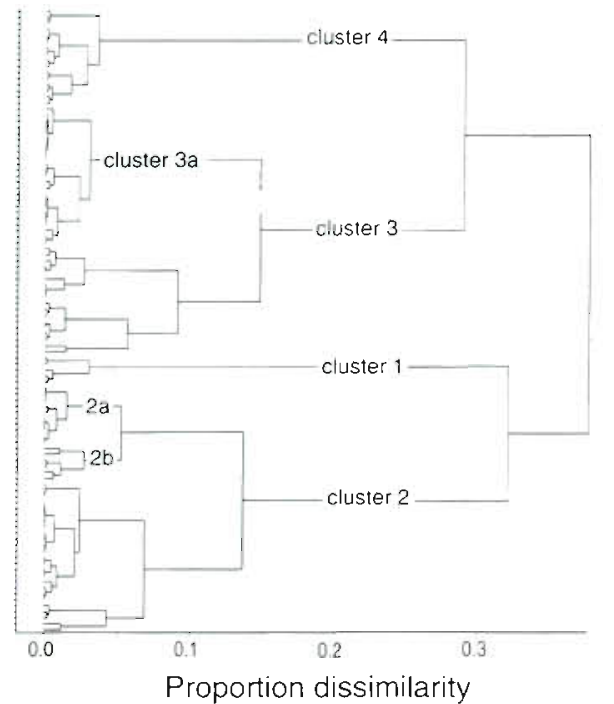

Fig. 2. Dendrogram produced by cluster analysis of hauls from all 6 cruises

mass classifications were made on the basis of both TS and temperature profiles, in these cases it was possible to distinguish water arriving from the northwest of South Georgia (assumed to be ACC) from water that was passing westward along the coast of South Georgia, although, this latter water type was generally of the type classified as ACC by Whitehouse et al. (1996). No water mass classifications were available for JB11. For classification of position around the island 3 regions were defined; west of $37.25^{\circ} \mathrm{W}(\mathrm{W})$, east of $36.75^{\circ} \mathrm{W}(\mathrm{E})$ and between $37.25^{\circ} \mathrm{W}$ and $36.75^{\circ} \mathrm{W}(\mathrm{M})$. Three categories of water depth were defined; shelf $<250 \mathrm{~m}$ (S), shelf break between $250 \mathrm{~m}$ and $2000 \mathrm{~m}$ (B) and off-shore $>2000 \mathrm{~m}$ (O). The distribution of net hauls within each individual cruise in relation to these water mass classifications can be seen in Fig. 1.

\section{RESULTS}

The results of the cluster analysis and overall PCA analysis for all cruises are presented first with a summary of general trends. Following this, more detailed analyses of specific cruises are presented.

\section{Cluster analysis}

Inspection of the dendrogram (Fig. 2) revealed that between 13 and $28 \%$ dissimilarity 4 clusters were observed. The stability of the classification over such a large range suggested some underlying biological differences between the clusters and evidence that the

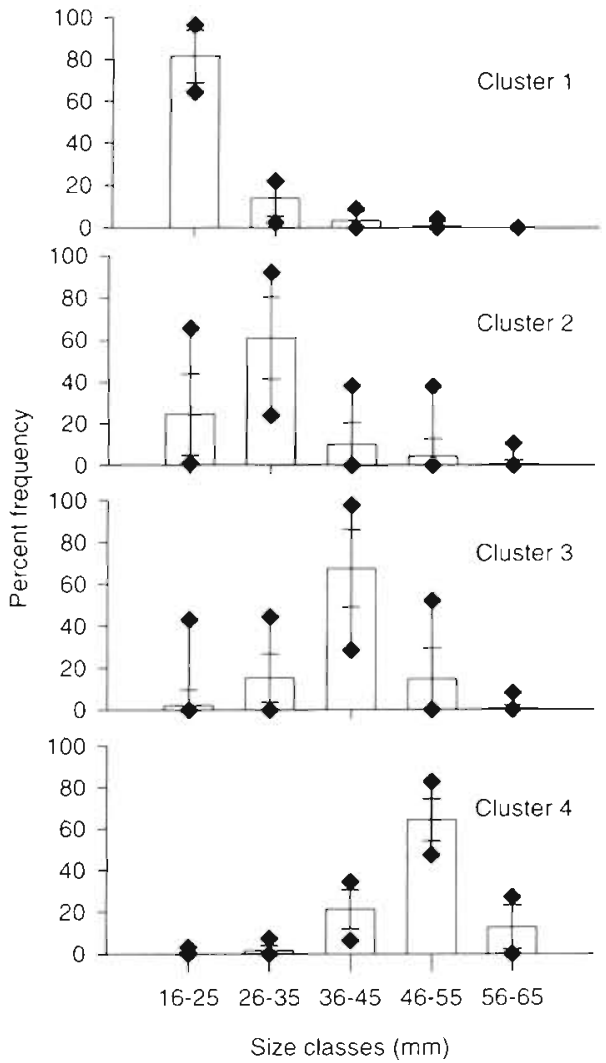

Fig. 3. Percentage frequency of krill in each $10 \mathrm{~mm}$ size class within the 4 chosen clusters. Histogram - mean; $(-) \pm \mathrm{SD} ;(\bullet)$ range

classification might not be arbitrary. These 4 clusters proved to have relatively simple biological characteristics; the mean distribution for each cluster having a different modal size class containing $>60 \%$ of the krill (Fig. 3). Other factors such as the shape of the distribution or the degree of bimodality also influenced the assignment of hauls to clusters. Cluster 1, dominated by the smallest size class ( 16 to $26 \mathrm{~mm}$ ), represents lengthfrequency distributions with just small krill (mean size $23.9 \mathrm{~mm}$ ) up to 2 yr old (i.e. $1+$ yr class). Cluster 2 (mean size $31.1 \mathrm{~mm}$ ) represents length-frequency distributions of krill larger than those in Cluster 1 but still containing many year $1+\mathrm{krill}$ (size class 26 to $36 \mathrm{~mm}$ ) but with some older krill as well $(2+$ to $4+$ yr classes; size classes 36 to $56 \mathrm{~mm}$ ). Cluster 3 represents distributions of medium-sized krill (mean size $41.4 \mathrm{~mm}$ ), mostly year $2+$ to $3+\mathrm{krill}$ (size class 36 to $46 \mathrm{~mm}$ ) but with a variable number of younger or older krill as well. Finally Cluster 4 represents the largest krill found (mean size $50.3 \mathrm{~mm}$ ) with length frequencies containing some year $2+$ and $3+$ krill (size class 36 to $46 \mathrm{~mm}$ ) but mainly krill older than year $3+$ (size class 46 to $56 \mathrm{~mm}$ ).

Cluster 1 and Cluster 4 (groupings of the smallest and largest krill respectively) were the simplest clus- 
ters. Krill within these clusters showed a high degree of similarity with other members of the cluster. In contrast, there was much more structure within Clusters 2 and 3 , the clusters with intermediate sized krill. In each case it was possible to recognize a number of subclusters which had distinct biological characteristics. For example in Cluster 2, subgroup 2a contained length frequencies from 3 cruises that had been classified as small, while subgroup $2 \mathrm{~b}$ (Fig. 2) contained length frequencies from 2 cruises that showed a marked biomodality (classified as Bs).

\section{Principal component analysis}

The first principal component accounted for $45 \%$ of the variance in the data, with the second component adding a further $34 \%$. Given that $>75 \%$ of the variance in the data was explained by just these 2 components, we do not consider any further principal components here.

Fig. 4a illustrates the ordering of hauls on the first 2 component axes with symbols to show the supplementary classification by type of histogram. The lines represent the eigen vectors corresponding to the projection of the length-frequency data onto the space of the first 2 principal components. The smallest krill (Cluster 1 as shown in Fig. 4 b) appear at the top left of the ordination and a clockwise progression around the figure corresponds to an increase in size and in cluster number with the largest krill found at the bottom of the ordination. Note that the bimodal distributions (Bs, B, Bl), which contain mixtures of small and large krill, tend to occur towards the centre of the diagram and between the areas of the ordination that represent unimodal distributions.

A general examination of these ordinations with symbols to show the environmental information (water depth, water mass origin and geographical region) reveals several patterns in the data set. For position around island (Fig. 4b), the samples with the smallest krill (Cluster 1) occurred only in the eastern region. In contrast, samples with the largest krill (Cluster 4) with 1 exception occurred in the west. In the plot showing informa- tion on water depth, all the off-shore samples appeared in the top half of the ordination in the area occupied by Clusters 1, 2 or 3 (Fig. 4c). Even more marked is the separation observed for classification by water mass (Fig. 4d). All samples classified as WS water are restricted to the very top left of the ordination where the hauls with the smallest krill are placed.

In the combined analyses reported above, it is possible that spatial differences might be aliased to some degree with interannual differences in krill population structure because the spatial coverage of samples did vary from year to year. For instance, all the samples identified as WS water are from 1 cruise (JB03) which had a very wide spatial coverage (Fig. 1); samples from this cruise consisted predominantly of small krill. In the following section we consider the spatial pattern occurring within each cruise separately to avoid any distortion potentially introduced by the aliasing.

\section{Individual cruise summaries}

$$
\text { JB03-Nov/Dec } 1981
$$

This cruise was designed to study variation around South Georgia and consequently had the greatest spa-

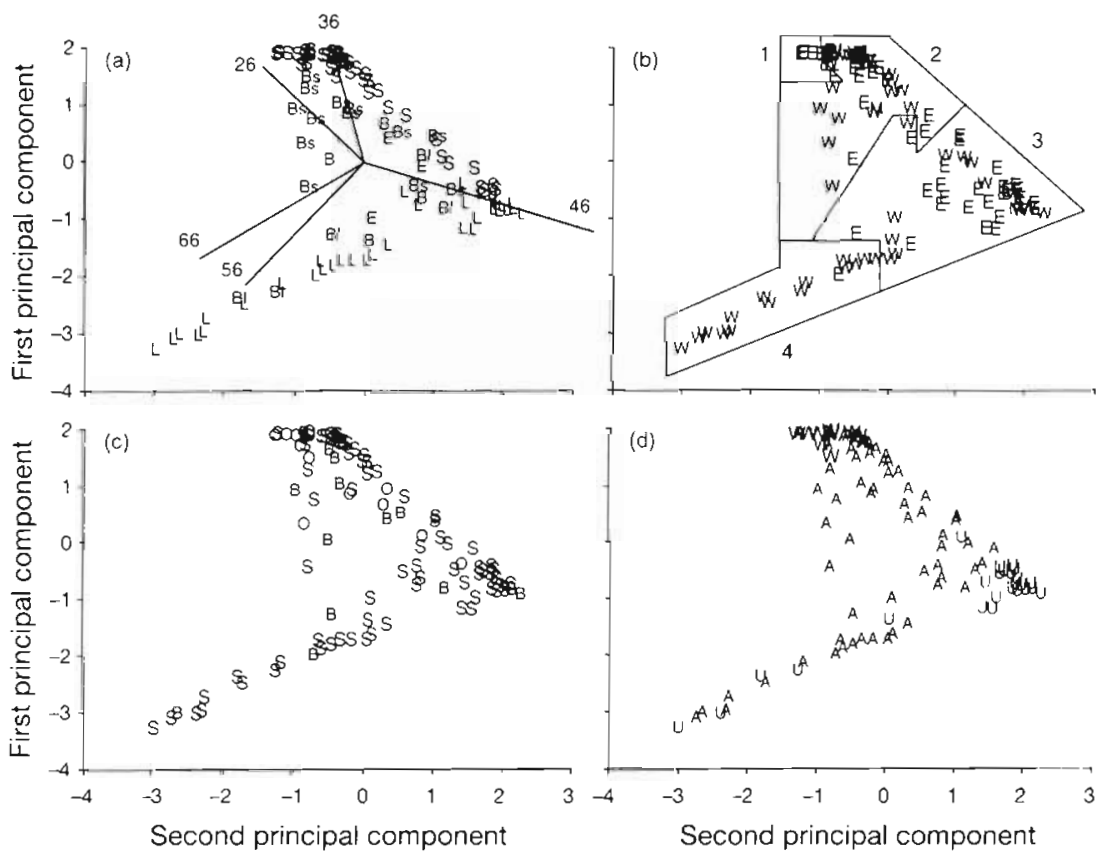

Fig. 4. First and second axes of PCA ordination of krill length-frequency distributions for all cruises: (a) distribution of hauls classified using type of length-frequency distribution-Small, Large, Bimodal, Bimodal small, Bimodal large, Even; lines represent eigen vectors in the space of the first 2 PCs. (b) Classification using position around island-East, West, Middle; numbered polygons show regions described by 4 clusters. (c) Classification using water depth -.Shelf, shelf Break, Off-shore. (d) Classification using water mass origin - Weddell Sea, Antarctic Circumpolar Current, Unidentified 

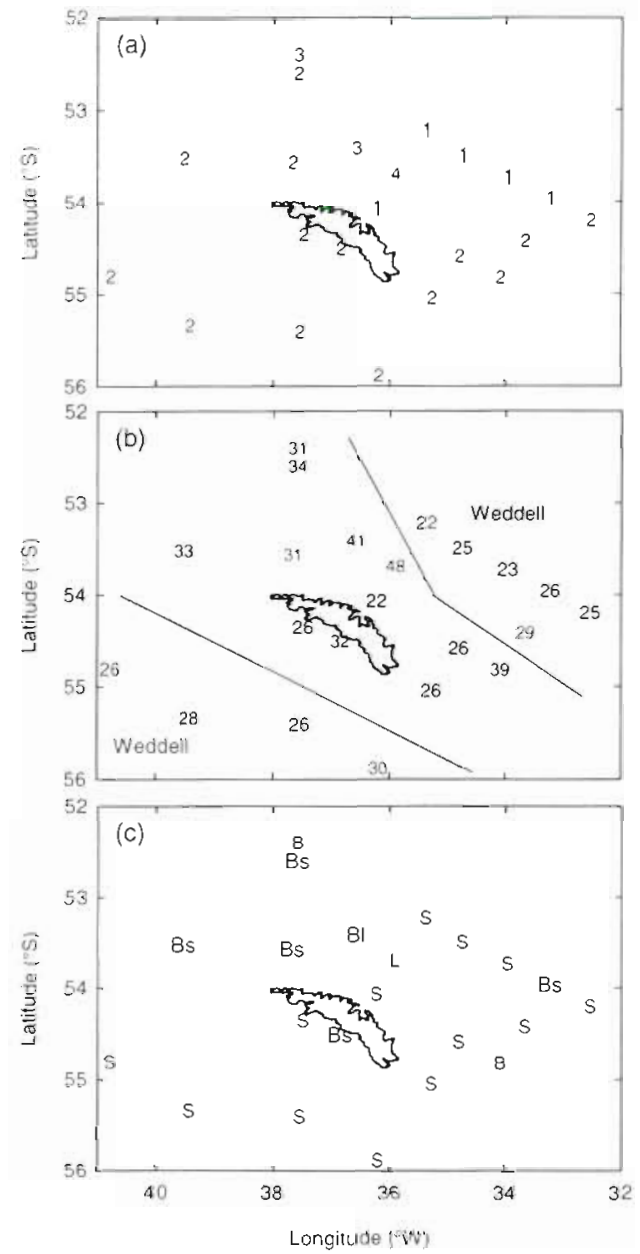

Fig. 5. Location of hauls during cruise JB03 (Nov/Dec 1981) showing (a) classification using cluster number (b) mean length ( $\mathrm{mm}$ ) of krill in each haul (c) classufication using type of length-frequency distribution (distribution types as in Fig. 4). Allocation of hauls to WS or ACC water indicated by lines

tial distribution of hauls with a total of 63 stations arranged in a regular grid. Clear differences in length frequencies between areas were identified (Fig. 5). Krill with bimodal length-frequency distributions (peaks at around $28 \mathrm{~mm}$ and $47 \mathrm{~mm}$, mean values 31 to $41 \mathrm{~mm}$, but with very few krill between 35 and $40 \mathrm{~mm}$ ) were generally found to the northwest of South Georgia (Fig. 5b,c). Two other net hauls with similar distributions were encountered; 1 on the southwest coast (mean size $31.8 \mathrm{~mm}$ ) and 1 to the southeast of the island (mean size $39.3 \mathrm{~mm}$ ). Otherwise to the south and east of the island krill were generally small juveniles classified as Cluster 1 or 2 (mean sizes 21.8 to $29.9 \mathrm{~mm}$ ). Such differences in spatial pattern were reinforced if we consider some of the subgroupings of Cluster 2 within the area. Although krill allocated to Cluster 2 occurred south and northwest of the island, only those classified as 2 b occurred in the northwest, while to the south of the island the hauls were classified as Cluster $2 \mathrm{a}$ indicative of a high level of similarity for samples within each of these areas.

An analysis of water mass distribution shows that ACC water from the Bellingshausen Sea encircled South Georgia, with WS water further off-shore to the southwest and northeast (Fig. 5a). This water mass distribution broadly corresponds to the distribution of krill length frequencies. In the ACC water, particularly to the northwest and southeast, there were predominantly bimodal distributions. In contrast, only small krill with generally unimodal length-frequency distributions were found in the WS water to the southwest and northeast.

This cruise was carried out earlier in the summer than any other cruise and so the mean size of krill found in the cruise is generally small. However, the main conclusion is still that smaller krill occur in WS water while larger krill occur in ACC water which confirms the general pattern observed in the combined data set.

\section{JB10-Jan/Feb 1990}

During cruise JB10 krill were sampled to the northwest and northeast of South Georgia. Krill to the northwest were mainly large adults (mean size 45.6 to $52.4 \mathrm{~mm}$ ) with unimodal length-frequency distributions and 8 of 10 hauls were classified as Cluster 4 (Fig. 6). Several hauls had krill larger than $55 \mathrm{~mm}$ and only 1 net contained krill as small as $30 \mathrm{~mm}$ (Cluster 3 ). In contrast, krill from the nor theast had a more bimodal size distribution with peaks at around 37 and $47 \mathrm{~mm}$ (mean size 35.4 to $44.8 \mathrm{~mm}$ ) and very few krill larger

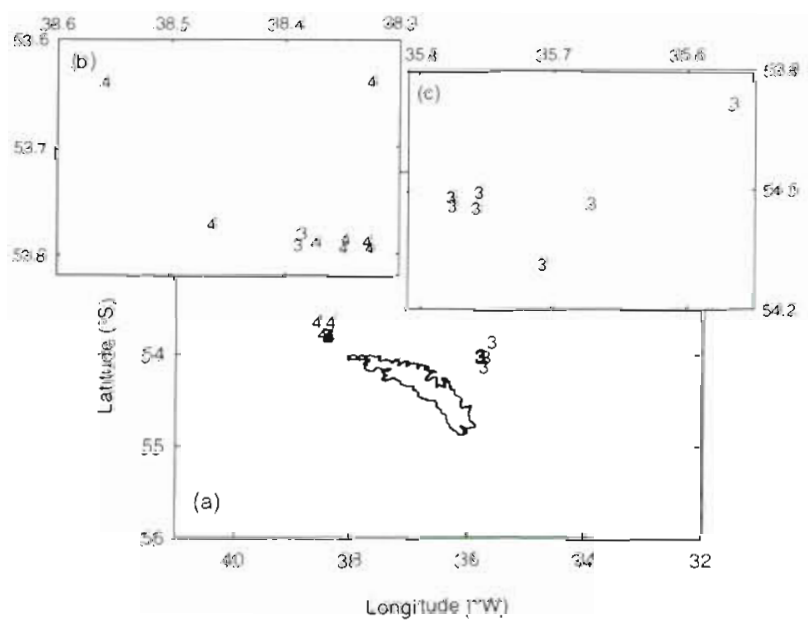

Fig. 6. Location of hauls during cruise JB10 (Jan/Feb 1990) showing (a) overall classification by cluster number, (b) cluster numbers for overlapping hauls around Bird Island and (c) northeast of Cumberland Bay 
than $55 \mathrm{~mm}$. All 7 hauls in this region were classified as Cluster 3. Thus there was a reasonable distinction between the type of krill length-frequency distribution found at the eastern and western ends of the island; larger krill (Cluster 4) occurred only at the western end of the island. Note, however, that in contrast to cruise JB03 no WS water was detected and so all the krill were caught in ACC water (Whitehouse et al. 1996).

$$
\text { JB11-Jan/Feb } 1991
$$

Krill were sampled along the north coast of South Georgia (Fig. 1). All hauls had very similar length-frequency distributions of krill (mean size 38.3 to $42.9 \mathrm{~mm}$ ). The size range (35 to $50 \mathrm{~mm}$ ) of the krill was limited, with a majority of krill in the $2+$ yr class and all distributions were classified as Cluster 3 . The similarity of hauls within this cruise is in sharp comparison to other cruises in the area, not only are all the hauls from within Cluster 3 but they occupy a subgroup of the cluster which itself shows very little variation (subgroup 3a in Fig. 2). No water mass classifications were available for this cruise. Biomass of krill in the area was low in this year (Brierley et al. 1998).

\section{JR06_Jan/Feb 1994}

In 1994 there were relatively few hauls where sufficient krill were caught to produce a length-frequency distribution. Six hauls, all taken near Bird Island at the northwest tip of South Georgia (Fig. 1), had a broad size range of krill (25 to $62 \mathrm{~mm}$ ) but the mean size of krill in each distribution was generally large (37.1 to

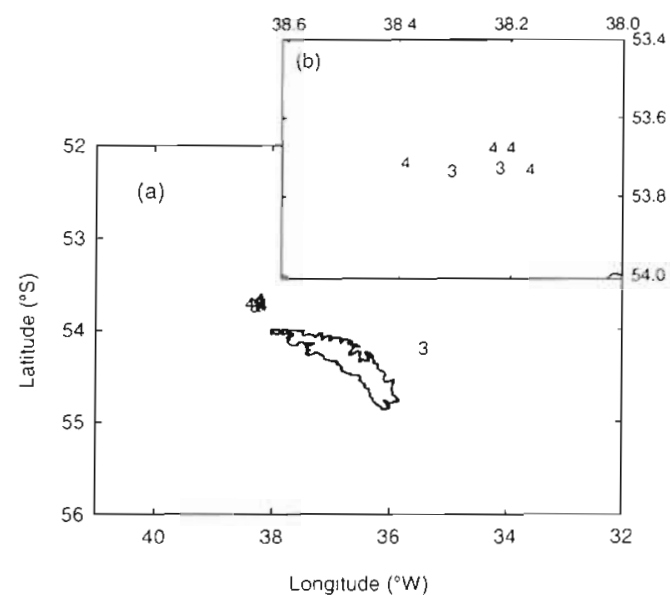

Fig. 7 Location of hauls during cruise JR06 (Jan/Feb 1994) showing (a) overall classification by cluster number and (b) cluster numbers for nearby hauls northwest of Bird Island
52.8 with four $>48 \mathrm{~mm}$; Clusters 3 or 4 ; Fig. 7). Four of these distributions were classed as bimodal size distributions with peaks at around 38 and $55 \mathrm{~mm}$ and all the events had some krill larger than $50 \mathrm{~mm}$. In contrast the single MNET haul to the east of Cumberland Bay (Fig.1) was classified as Cluster 3 with mean sizes in the 6 nets ranging from 38.2 to $40.6 \mathrm{~mm}$ and unimodal distributions (krill 30 to $48 \mathrm{~mm}$ ). Although there was thus some suggestion of a difference between the krill found at the 2 ends of the island, with larger krill again occurring at the western end, this can only be a tentative conclusion given the number of samples taken especially at the eastern end (see also 'Discussion'). All the samples at the western end of the island appear to be in ACC water although subtle differences in water structure were apparent (Trathan et al. 1997). There was no classification of water type for the single sample in the east.

$$
\text { JR11-Jan/Feb } 1996
$$

This cruise, the first of the PES core programme surveys (Brierley et al. 1997), had a good spatial distribution of samples north of South Georgia (Fig. 1). Some additional krill were taken to the west of South Georgia near Shag Rocks, and further north, near the Antarctic Polar Front, but these were not included in the cluster and PCA analyses. The samples around South Georgia were grouped in 2 main areas; to the northeast of the island (eastern core box) and to the northwest of Bird Island (western core box). Some additional samples were taken in the vicinity of Cumberland Bay (Fig. 1).

Of the 17 hauls sampled around the north-west tip of South Georgia (western core box), 13 were classified as Cluster 2 and contained small krill (mean sizes 27.2 to $39.6 \mathrm{~mm}$; Fig. 8). The four remaining hauls in this western area tended to be larger (mean sizes 37.2 to $50.9 \mathrm{~mm}$ ) and were classified as Clusters 3 or 4 . There was no obvious trend of change in size with water depth; thus, the off-shore hauls were represented by Clusters 2 and 3 while the largest krill (Cluster 4) were found on shelf in amongst groups of small krill (Cluster 2).

Of the 9 hauls from the eastern core box, 7 contained mostly juveniles and krill less than $40 \mathrm{~mm}$ long (mean sizes 25.6 to $30.2 \mathrm{~mm}$ ), the length-frequency distributions were markedly unimodal, corresponded well to year $1+$ krill, and were classified as Cluster 2 (Fig. 8). The other 2 hauls in the east contained a few larger animals, giving rise to bimodal length-frequency distributions, with the most easterly sample containing the largest krill (maximum size $59 \mathrm{~mm}$; mean size $36.3 \mathrm{~mm}$ ), however, both these hauls were classified as 


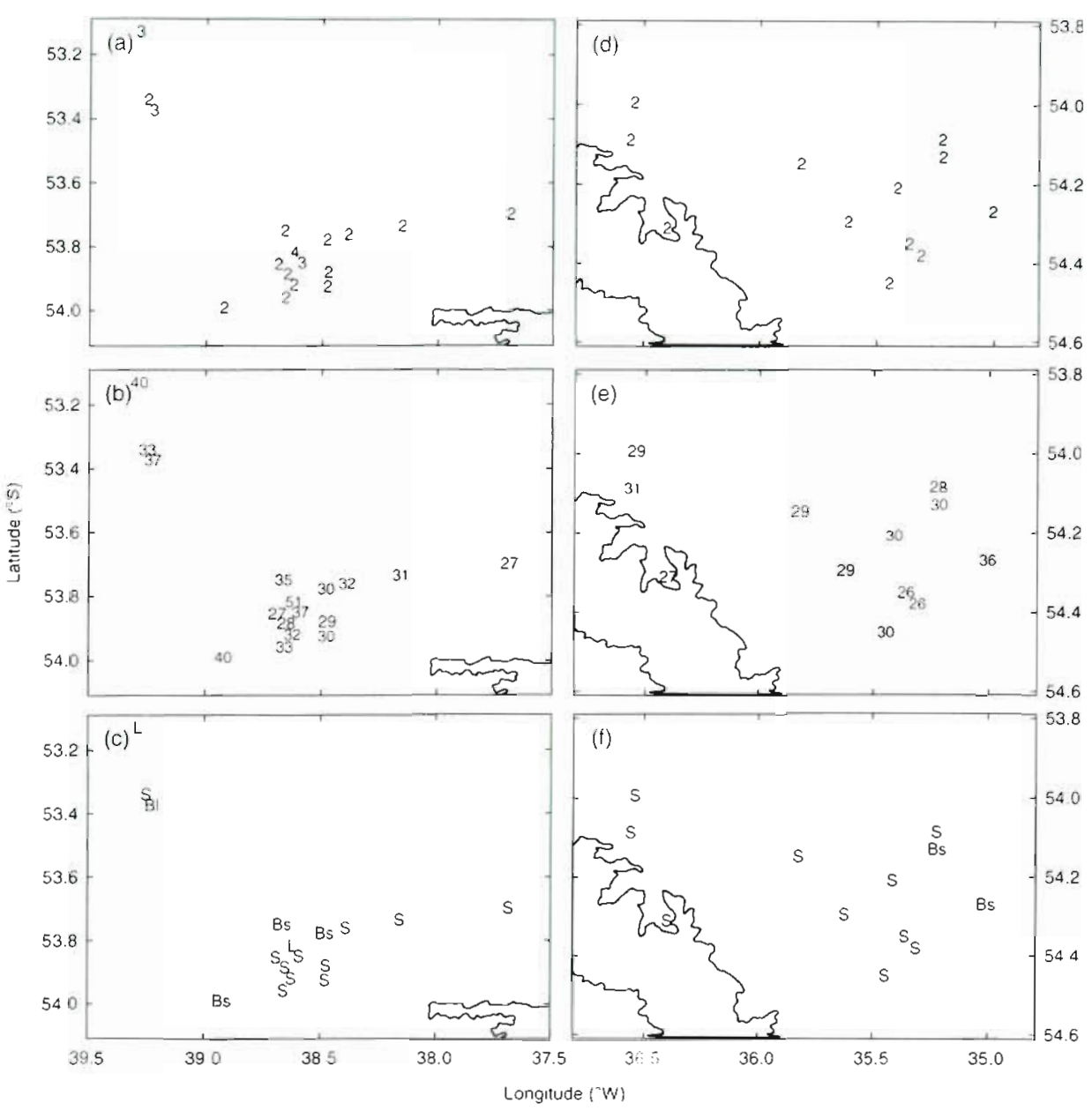

Fig. 8. Location of hauls during cruise JR11 (Jan/Feb 1996). (a) Classification by cluster number, (b) mean length ( $\mathrm{mm}$ ) and (c) krill distribution type for hauls northwest of Bird Island. (d) Cluster'number, (e) mean length (mm) and (f) krill distribution type for hauls off Cumberland Bay and at the eastern end of South Georgia. Overall distribution of hauls shown in Fig. 1
Cluster 2. The 3 hauls off Cumberland Bay were very similar to those of the eastern core box, with predominantly small immature krill (mean sizes 27.4 to $30.6 \mathrm{~mm}$ ) and classified as Cluster 2. Although krill from Cluster 2 formed the dominant grouping of krill at both east and west ends of the island, when the distribution of subgroups within Cluster 2 were considered, more differences in spatial pattern were apparent. Thus, krill classified as subgroup $2 a$ were only found at the eastern end of the island.

Samples taken from the area of the Polar Front (PFZ) around the Maurice Ewing Bank, although not formally included in this analysis had large unimodal distributions (mean sizes 41.9 to 45.0 mm). The 4 hauls from Shag Rocks all showed similar length frequencies with unimodal distributions with means ranging from 33.9 to $37.8 \mathrm{~mm}$

Water mass classification for the entire area sampled by nets was considered to be ACC water using the criteria of Whitehouse et al. (1996). However, subtle differences were again observed within the area; thus, it was possible to distinguish shelf water at the inshore stations that was warmer and fresher than that occurring off-shore. In addition, ACC water identified as regimes $2 \& 3$ by Trathan et al. (1997) could be distinguished.

\section{JR17-Dec 1996/Jan 1997}

The second core programme survey revisited the 2 core boxes sampled in JR11 and so provides a spatially comparable set of length-frequency distributions. Mean size of krill in the eastern core box varied between $27.5 \mathrm{~mm}$ and $44.8 \mathrm{~mm}$ (Fig. 9). Four of the 6 krill hauls in this area were classified as Cluster 3 representing unimodal year $2+$ krill; the other 2 samples did contain some smaller krill and were classified as Cluster 2. Krill in the western core box were generally large with mean sizes of 42.6 to $49.2 \mathrm{~mm}$ (Cluster 3 or 4). The length-frequency distributions were dominated by a mode at $\sim 50 \mathrm{~mm}$, suggesting that many of these krill were older than year $2+$ (the expected age if the krill were from the same year class as the domi- 

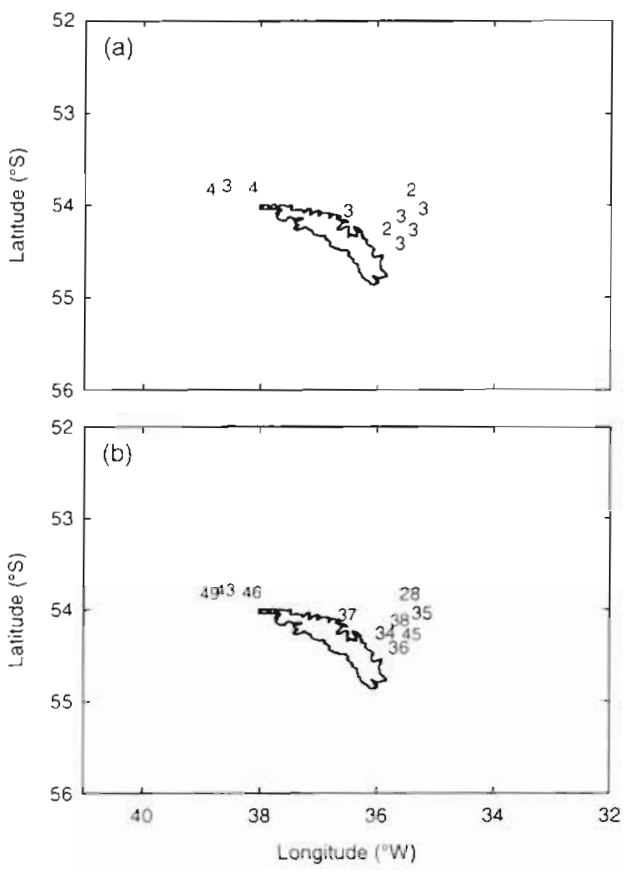

Fig. 9. Location of hauls during cruise JR17 (Dec 1996/Jan 1997) showing (a) classification by cluster number and (b) mean length (mm) of krill in each haul

nant year 1+ krill observed in the previous year). Once again, although Cluster 3 krill samples were found at both ends of the island, all but 1 of these from the eastern end of the island came from a different subgroup than those found at the western end of the island.

Water mass classification indicated that the water in both boxes showed less variation than in JR11 and was typical of ACC water which had been warmed as it passed along the north eastern coast of South Georgia.

\section{DISCUSSION}

In 5 of the 6 cruises examined a distinct spatial pattern in the length-frequency distribution was found; krill at the western end of the island tended to be larger than krill at the eastern end of the island. However, before we accept the hypothesis that there are consistent spatial patterns in the length-frequency structure of the population distribution, we must consider whether there may be any methodological biases that could affect our conclusions.

Different nets were used during the study period and so differences in net selectivity could have occurred. While some nets have a tendency to catch a particular size of krill (Kasatkina 1996), this effect appears minimal for comparisons between scientific nets (Anon.
1991). In addition this effect has been minimized because only 1 or 2 nets have been used to collect the majority of the samples within any cruise. The cruise most likely to have suffered from net-induced bias was JRO6 (1994). In this case samples at the western end of the island were taken with a RMT25 net while the sample from the eastern end was taken with a MNET. Given the large difference in mouth areas (Table 1) we cannot exclude the possibility that, in this cruise, the smaller krill at the eastern end of the island were a result of net selection rather than regional differences. However, we believe that this is not a problem within the other cruises because, when different nets were used, each type of net caught a range of krill sizes, thus representatives of each cluster found within a cruise were taken by each type of net.

We must also consider the number of net samples taken in relation to the number required to obtain representative samples of the local population. Watkins et al. (1990) gave some indication of the confidence limits of single samples from a series of studies. While many hauls ( $\mathrm{n}>20$ ) may be required to remove the effect of heterogeneity completely, fewer hauls are valid provided the appropriate confidence intervals are used. In this study the use of large size classes and only 4 clusters should make the analysis relatively insensitive to inter-swarm heterogeneity and ensure that only relatively large changes in population structure are picked out.

We must also consider the effect of the growth of krill during a survey. During the Antarctic summer, krill can grow at up to $0.18 \mathrm{~mm} \mathrm{~d}^{-1}$ (Rosenberg et al. 1986) equivalent to $1.2 \mathrm{~mm} \mathrm{wk}^{-1}$. Therefore in a data set collected over the period of a month, the mean size of the krill could have increased by up to $5 \mathrm{~mm}$. Inspection of the longest cruise data sets (JB03 and JR11) reveal that there was no recognizable trend of change in krill length with time. Furthermore many of the differences between areas arose because the year class composition of the population changed rather than due to slight increases in the size of any individual year class mode.

Even taking the above caveats into account, the basic pattern remains clear; in cruises JB03, JB10, JR11 and JR17 there was evidence that the krill at the western end of the island were larger than krill at the eastern end of the island. While in only 1 yr (JB11, 1990/1991) were the length frequencies from all the nets very similar despite being spread over a wide area. We therefore accept the hypothesis that, in general, the mean size of krill at the western end of the island was larger than that at the eastern end. This was usually a result of varying numbers of large krill occurring in the western group that were not present in the eastern area, that is, the year class composition was different at the 2 ends of the island. 
How do such differences arise? Krill around South Georgia are considered a non-reproducing population (Ward et al. 1990) and so have to be carried towards South Georgia in the prevailing currents of the ACC. The generally accepted hypothesis is that krill are transported along the northern side of the island from east to west (Hofmann et al. 1998). Can the differences that we observe accur simply by processes which act on the krill population as it is moving along the coast or do we have to seek alternative explanations? Here we propose that differences in population structure around the island could arise in 2 basic ways. First, because the physical conditions prevailing at the 2 ends of the island may be different; we hypothesize that there might be differences in, for instance, retention and mortality rates which act as krill are moving along the coast. Second, krill at the western end may not arrive by the same route as those found at the eastern end of the island; different environmental conditions may be encountered during transport from the source area to South Georgia or krill may have come from different source areas which have different population structures. Below we consider what evidence is available to support these ideas. Although we discuss each possibility separately, the population structure observed at South Georgia may result from a combination of these effects. These effects may be manifest in the krill population in 2 ways. Thus, differences in the length frequencies arise (1) through changes in the relative composition of year classes (large krill seen at the western end of South Georgia are likely to be at least 1 yr older than the majority of krill at the eastern end of the island (JB03, JR11 and JR17)) or (2) differences could occur within a year class due to krill experiencing different environmental conditions (particularly of chlorophyll and temperature) which then results in differential growth rates (Quetin et al. 1994).

\section{Processes along the north coast of South Georgia}

Let us first consider processes occurring within the sampled area around South Georgia. A simple hypothesis might be that small krill arrive at the eastern end of the island and then grow as they are transported along the coast to the west. At the eastern end of the island current velocities off-shelf vary between 40 and $60 \mathrm{~cm} \mathrm{~s}^{-1}$ (Brandon et al. 1999). This would produce transit times of between 3.5 and $7 \mathrm{~d}$ corresponding to a growth of up to $1.2 \mathrm{~mm}$ (Rosenberg et al. 1986). Clearly many of the differences are significantly greater than this and so such a simple explanation seems unlikely, even for differences between off-shore samples in cruise JBO3 (Fig. 5).
For krill found over the shelf such a simple calculation is inappropriate. Shelf flows are much more variable in velocity and direction (Brandon et al. 1999) and so krill found on the shelf may have been retained for considerable time (Atkinson \& Peck 1990, Latogursky et al. 1991). We postulate that some krill seen at the western end of the island may have arrived at the eastern end of the island in a previous year. Inspection of FRAM data (Trathan et al. 1997) indicates the possibility of a slow-moving gyre to the north of Bird Island. Retention on the shelf may also be facilitated by the presence of a shelf break front where shelf and offshore water may be connected at depth but are separated at the surface (Brandon et al. 1999). Thus, a shelf population of krill may remain in the area for some time while an off-shore population is more transient. Certainly the presence of the older year class at the western end may be indicative of such a process.

\section{Processes occurring at the scale of the Scotia Sea}

Differences in spatial pattern of length-frequency could be due to krill arriving by different routes from the western Scotia Sea or perhaps from different source areas. Siegel (1987) found differences between the Weddell and Bellingshausen Sea krill in the size of juvenile krill with year $1+$ krill smaller in the Weddell Sea, although there were differences in the time of year when these comparisons were made. Although other year classes were of comparable length, he found no $5+$ yr class in Weddell Sea. Thus, the largest size class was missing and so maximum size was lower than in the Peninsula area. Also spatial differences were apparent; a full set of age classes was only found at the eastern end or beginning of the Weddell gyre. Siegel et al. (1990) sampled krill from the area of the Weddell Scotia Confluence (WSC) in 1988/89 and found a series of different clusters of krill distributed as a somewhat complex banding of large and small krill from north to south; this was interpreted as krill from the Bellingshausen Sea in the north and krill from the Weddell Sea in the south. Again there was good evidence that eastern Weddell Sea krill were smaller than Bellingshausen Sea krill for a given age. Certainly the presence of small krill in WS water in contrast to the larger krill in ACC water show that such a large-scale process may be important in some years. In addition there could be interannual differences in recruitment within the source areas but such variation in recruitment throughout the Scotia Sea is beyond the scope of the present paper.

Anon. (1991) indicated that krill population structure in Scotia Sea was well correlated with water mass structure-small krill at ice edge in Weddell Sea, 
medium krill in WSC and the largest krill north of the meandering confluence zone. We postulate that $\mathrm{ACC}$ water passing along the outside of the Antarctic Peninsula contains large krill that have migrated off-shore from the South Shetland Islands. This water usually passes to the north of South Georgia where it mixes with water that has come along the east coast of South Georgia. Thus, large krill to the north of South Georgia and up near the PFZ could have originated from a different area from those krill passing up the east coast of South Georgia.

\section{Implications for predator distributions}

Predator-prey studies conducted in 1986 indicated that the size of krill caught by macaroni penguins (Hill et al. 1996) and by other krill predators (Reid et al. 1996) were significantly larger than those caught in nets. Such selective predation could alter the lengthfrequency distribution by reducing the proportion of large krill sampled. However, in 1986, krill taken in nets throughout the study area (western end of South Georgia) were the largest caught around South Georgia since net sampling with RMT8 nets began in 1978 (British Antarctic Survey unpubl. data). More recent analyses combining predator and net samples taken since 1990 (Reid et al. 1999) indicate that Antarctic fur seals consistently took krill with a modal size of at least $42 \mathrm{~mm}$ but macaroni penguins took krill smaller than this if they were present (as determined from net sampling). Antarctic fur seal colonies are larger and more numerous at the western end of the island (Boyd 1993). Therefore it appears that the fur seals are more numerous in the areas where the large krill are more likely to be found. However, it may be too simple to assume that this is the underlying cause for differences in fur seal distribution because other factors, such as quantity and reliability of available krill biomass and suitable breeding habitat ashore, may also be important.

\section{Conclusions}

Differences were observed between the krill population structure at the western and eastern ends of the island of South Georgia. Krill at the eastern end of the island were often smaller or lacked the presence of larger year classes that were found at the western end of the island. We postulate that such differences may arise because of krill retention at the western end of the island and because krill at the 2 ends of the island may have come from 2 different source areas (Weddell Sea and Bellingshausen Sea). A full understanding of what is happening at South Georgia will only become apparent as krill source, flux across the Scotia Sea and retention around South Georgia are integrated together. A recent BAS cruise (JR26) to study the genetic characteristics of krill across the Scotia Sea offers considerable potential for identifying source areas of krill. Such work combined with large-scale, integrated studies on processes influencing interannual variability across the Scotia Sea now provide the potential for a significant step forward in understanding the ecology of Euphausia superba in the Atlantic sector of the Southern Ocean.

Acknowledgements. We thank the officers, scientists and crew of RRS 'John Biscoe' and 'James Clark Ross' who helped collect the net samples on the various cruises. We thank H. J. Hill, J. Measures and R. Mitchell for help with measuring krill and organizing data. We thank E. J. Murphy and J. Priddle for comments and discussions on drafts of the manuscript.

\section{LITERATURE CITED}

Amos AF (1984) Distribution of krill (Euphausia superba) and the hydrography of the Southern Ocean: large-scale processes. J Crustac Biol 4(Spec No. 1):306-329

Anon. (1991) Non-acoustic krill data analysis workshop. BIOMASS Rep Ser 66:1-59

Anon. (1993) Statistical bulletin, Vol. 5. CCAMLR, Hobart, 1983-1992 CCAMLR-SB/93/5

Atkinson A, Peck JM (1990) The distribution of zooplankton in relation to the South Georgia shelf in summer and winter. In: Kerry KR, Hempel G (eds) Antarctic ecosystems. Ecological change and conservation. Springer-Verlag, Berlin, p 159-165

Boyd [ (1993) Pup production and distribution of breeding Antarctic fur seals (Arctocephalus gazella) at South Georgia. Antarct Sci 5:17-24

Brandon MA, Murphy EJ, Whitehouse MJ, Trathan PN, Murray AWA, Bone DG, Priddle J (1999) The shelf break front to the east of the sub-Antarctic island of South Georgia. Cont Shelf Res 19:799-819

Brierley AS, Watkins JL, Murray AWA (1997) Interannual variability in krill abundance at South Georgia. Mar Ecol Prog Ser 150:87-98

Brierley AS, Watkins JL, Goss C, Wilkinson MT, Everson I (1998) Acoustic estimates of krill density at South Georgia during 11 austral summers between 1981 and 1998. CCAMLR, Hobart, WG-EMM-98/51

Croxall JP, McCann TS, Prince PA, Rothery P (1988) Reproductive performance of seabirds and seals at South Georgia and Signy Island, South Orkney Islands, 1976-1987: implications for Southern Ocean monitoring studies. In: Sahrhage D (ed) Antarctic Ocean and resources variability. Springer-Verlag, Berlin, p 261-285

Everson I (1976) Antarctic krill: a reappraisal of its distribution. Polar Rec 8:15-23

Everson I (1984) Zooplankton. In: Laws RM (ed) Antarctic ecology, Vol. 2. Academic Press, London, p 463-490

Everson I, Goss C (1991) Krill fishing activity in the southwest Atlantic. Antarct Sci 3:351-358

Fedulov PP, Murphy EJ, Shulgovsky KE (1996) Environmentkrill relations in the South Georgia marine ecosystem. CCAMLR Sci 3:13-30

Hill HJ, Trathan PN, Croxall JP, Watkins JL (1996) A comparison of Antarctic krill Euphausia superba caught by nets 
and taken by macaroni penguins Eudyptes chrysolophus: evidence for selection? Mar Ecol Prog Ser 140:1-11

Hofmann EE, Klinck JM, Locamini RA, Fach B, Murphy EJ (1998) Krill transport in the Scotia Sea and environs. Antarct Sci 10:406-415

Jazdzewski K, Dzik J, Porebski J, Rakusa-Suszczewski S, Witek Z, Wolnomiejski N (1978) Biological and populational studies on krill near South Shetland Islands, Scotia Sea and South Georgia in the summer 1976. Pol Arch Hydrobiol 25:607-631

Kasatkina SM (1996) On selectivity of commercial and research trawls when catching krill. CCAMLR, Hobart, WG-EMM-96/34

Latogursky Vl, Makarov RR, Maklygin LG (1991) Distribution, biomass and characteristics of the Euphausia superba fishery around South Georgia (Subarea 48.3). In: Selected Scientific Papers 1990 (SC-CAMLR-SSP/7). CCAMLR, Hobart, p 123-147

Mackintosh NA (1973) Distribution of post-larval krill in the Antarctic. Discovery Rep 36:95-156

Marr JWS (1962) The natural history and geography of the Antarctic krill (Euphausia superba Dana). Discovery Rep $32: 33-464$

Morris DJ, Watkins JL, Ricketts C, Buchholz F, Priddle J (1988) An assessment of the merits of length and weight measurements of Antarctic krill Euphausia superba. Br Antarct Surv Bull 79:27-50

Murphy EJ, Trathan PN, Everson I, Parkes G, Daunt F (1997) Krill fishing in the Scotia Sea in relation to bathymetry, including the detailed distribution around South Georgia. CCAMLR Sci 4:1-17

Payne RW, Lane PW, Digby PGN, Harding SA, Leech PK, Morgan GW, Todd AD, Thompson R, Tunnicliffe-Wilson G, Welham SJ, White RP (1993) GENSTAT 5 reference manual. Oxford University Press, Oxford

Priddle J, Croxall JP, Everson I, Heywood RB, Murphy EJ, Prince PA, Sear CB (1988) Large-scale fluctuations in distribution and abundance of krill-a discussion of possible causes. In: Sahrhage D (ed) Antarctic Ocean and resources variability. Springer-Verlag, Berlin, p 169-182

Quetin LB, Ross RM, Clarke A (1994) Krill energetics: seasonal and environmental aspects of the physiology of Euphausia superba. In: El-Sayed SZ (ed) Southern Ocean ecology: the BIOMASS perspective. Cambridge University Press, Cambridge, p 165-184

Editorial responsibility: Otto Kinne (Editor),

Oldendorf/Luhe, Germany
Reid K, Arnould JPY (1996) The diet of Antarctic fur seals Arctocephalus gazella during the breeding season at South Georgia. Polar Biol 16:105-114

Reid K. Trathan PN, Croxall JP, Hill HJ (1996) Krill caught by predators and nets: differences between species and techniques. Mar Ecol Prog Ser 140:13-20

Reid KG, Watkins JL, Croxall JP, Murphy EJ (1999) Krill population dynamics at South Georgia 1991-97, based on data from predators and nets. Mar Ecol Prog Ser 177 : $103-114$

Rosenberg AA, Beddington JR, Basson M (1986) Growth and longevity of krill during the first decade of pelagic whaling. Nature 324:152-154

Siegel V (1987) Age and growth of Antarctic Euphausiacea (Crustacea) under natural conditions. Mar Biol 96: $483-495$

Siegel V, Bergström B, Stromberg JO, Schalk PH (1990) Distribution, size frequencies and maturity stages of krill, Euphausia superba, in relation to sea-ice in the northern Weddell Sea. Polar Biol 10:549-557

Trathan PN, Priddle J, Watkins JL, Miller DGM, Murray AWA (1993) Spatial variability of Antarctic krill in relation to mesoscale hydrography. Mar Ecol Prog Ser 98: $61-71$

Trathan PN, Murphy EJ, Croxall JP, Everson I (1996) Use of at-sea distribution data to derive potential foraging ranges of macaroni penguins during the breeding season. CCAMLR, Hobart, WG-EMM-96/59

Trathan PN, Brandon MA, Murphy EJ (1997) Characterization of the Antarctic Polar Frontal Zone to the north of South Georgia in summer 1994. J Geophys Res 102: 10483-10497

Voronina NM (1974) An attempt at a functional analysis of the distributional range of Euphausia superba. Mar Biol 24: $347-352$

Ward P, Atkinson A, Peck JM, Wood AG (1990) Euphausiid life cycles and distribution around South Georgia. Antarct Sci 2:43-52

Watkins JL, Morris DJ, Ricketts C, Murray AWA (1990) Sampling biological characteristics of krill: effect of heterogeneous nature of swarms. Mar Biol 107:409-415

Whitehouse MJ, Priddle J, Symon C (1996) Seasonal and annual change in seawater temperature, salinity, nutrient and chlorophyll a distributions around South Georgia, South Atlantic. Deep-Sea Res I 43:425-443

Submitted: April 21, 1998; Accepted: March 29, 1999

Proofs received from author(s): October 20, 1999 